\title{
Copy Number Variants in Short Children Born Small for Gestational Age
}

Jan M. Wit ${ }^{a}$ Hermine A. van Duyvenvoorde ${ }^{b}$ Jan B. van Klinken ${ }^{c}$ Janina Caliebe ${ }^{d}$

Cathy A.J. Bosch ${ }^{b}$ Julian C. Lui ${ }^{\mathrm{e}}$ Antoinet C.J. Gijsbers ${ }^{\mathrm{b}}$ Egbert Bakker ${ }^{\mathrm{b}}$

Martijn H. Breuning ${ }^{b}$ Wilma Oostdijk ${ }^{a}$ Monique Losekoot $^{b}$ Jeffrey Baron ${ }^{\mathrm{e}}$

Gerhard Binder $^{d}$ Michael B. Ranke ${ }^{d}$ Claudia A.L. Ruivenkamp ${ }^{b}$

Departments of a Pediatrics, ${ }^{\mathrm{b}}$ Clinical Genetics and ${ }^{\mathrm{c} H u m a n}$ Genetics, Leiden University Medical Center, Leiden, The Netherlands; 'Paediatric Endocrinology Section, Children's Hospital, University of Tübingen,

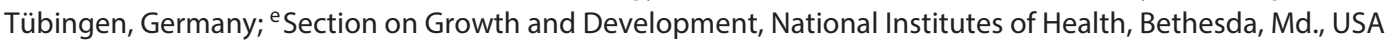

\section{Key Words}

Short stature · Small for gestational age · Growth · Copy number variations. Single nucleotide polymorphism array . Genetics

\footnotetext{
Abstract

Background/Aims: In addition to genome-wide association studies (GWAS), height-associated genes may be uncovered by studying individuals with extreme short or tall stature. Methods: Genome-wide analysis for copy number variants (CNVs), using single nucleotide polymorphism (SNP) arrays, was performed in 49 index cases born small for gestational age with persistent short stature. Segregation analysis was performed, and genes in CNVs were compared with information from GWAS, gene expression in rodents' growth plates, and published information. Results: CNVs were detected in 13 cases. In 5 children a known cause of short stature was found: UPD7, UPD14, a duplication of the SHOX enhancer region, an IGF1R deletion, and a 22q11.21 deletion. In the remaining 8 cases, potential pathogenic CNVs were detected, either de novo $(n=1)$, segregating $(n=2)$, or not segregating
}

with short stature $(n=5)$. Bioinformatic analysis of the de novo and segregating CNVs suggested that HOXD4, AGPS, PDE11A, OSBPL6, PRKRA and PLEKHA3, and possibly DGKB and TNFRSF11B are potential candidate genes. A SERPINA7 or $N R K$ defect may be associated with an X-linked form of short stature. Conclusion: SNP arrays detected 5 known causes of short stature with prenatal onset and suggested several potential candidate genes.

(c) 2014 S. Karger AG, Basel

\section{Introduction}

Height, in childhood as well as in adulthood, is predominantly determined by genetic factors, and is considered a classic polygenic trait. It is now clear that, according to genome-wide association studies (GWAS), the number of loci associated with adult height is at least 180 [1]. The majority of the genes located in or close to these loci identified by GWAS have not been associated with severe growth disorders.

\section{KARGER}

E-Mail karger@karger.com

www.karger.com/hrp (c) 2014 S. Karger AG, Basel

$1663-2818 / 14 / 0825-0310 \$ 39.50 / 0$
Jan M. Wit, MD, PhD

Department of Pediatrics, S6-P

Leiden University Medical Center

PO Box 9600, NL-2300 RC Leiden (The Netherlands)

E-Mail j.m.wit@lumc.nl 
In the diagnostic process of a child with short stature, the clinician should start with a thorough medical history and physical examination, followed by targeted or screening laboratory and radiologic investigations, and in many cases tests to estimate growth hormone (GH) secretory status [2]. If physical characteristics are suspected for a congenital syndrome, consultation of a clinical geneticist is usually indicated [3]. This can lead to the suspicion of a specific disorder, which can then be confirmed with an appropriate genetic test (the candidate gene approach). In case of a low circulating IGF-I, specific genetic tests can be performed to establish the diagnosis $[4,5]$. However, in most cases the clinician ends up with no diagnosis and classifies the condition under the term idiopathic short stature (ISS) or persistent short stature after being born small for gestational age (SGA) of unknown origin, depending on birth size [6]. In such cases, one can consider to perform a genome-wide analysis for copy number variants (CNVs) using single nucleotide polymorphism (SNP) arrays [7-9].

SNP array analysis is a powerful tool to detect CNVs. A major advantage of SNP arrays in comparison to arraybased comparative genomic hybridization is that it offers SNP genotyping, which enables the detection of copynumber neutral chromosomal aberrations such as uniparental disomies (UPD) and loss of heterozygosity (LOH). UPD can result in rare recessive disorders, or developmental problems due to the effects of genomic imprinting. An even more powerful tool which is expected to be widely available in the coming years is whole-exome sequencing [10-12]. With this technique small CNVs and point mutations in coding regions of the genome can be detected.

In two previous papers from our group $[5,13]$ we have described the results of a candidate gene approach in children with short stature, either associated with a low birth size (SGA) or with a normal birth size (ISS) [14]. In a third paper we described the results of a genome-wide analysis for CNVs using SNP arrays in children with short stature [7]. Three studies on genome-wide association analysis of CNVs and stature showed that children with short stature had a greater global burden of lower frequency and rare deletions and a greater average CNV length than controls $[8,9,15]$. In the latter two reports, $10-16 \%$ of patients with short stature carried a disease-causing CNV $[8,9]$. These observations suggest that CNVs might contribute to genetic variation in stature in the general population.

In the present paper we describe the results of a genome-wide analysis for CNVs in short children born SGA, in a further effort to identify novel gene variants associated with short stature.

\section{Subjects and Methods}

\section{Patients}

Patients were selected from the Tübingen fraction $(n=199)$ of the NESTEGG cohort, consisting of children with short stature (height after the age of 3 years $\leq-2$ SDS according to Swiss references [16] that are representative for this South-West German population) who presented between 2002 and 2005 at the Tübingen Pediatric Endocrinology Outpatient Clinic. Selection criteria included a low birth weight and/or length (SGA) of unknown etiology; availability of sufficient good quality DNA, and absence of additional abnormalities at medical history, physical examination, biochemical investigations, and radiography of the hand and wrist, except for dysmorphic features or skeletal variants in some cases. Very preterm birth ( $<30$ weeks of gestation) and complicated postnatal period (ventilation $>72 \mathrm{~h}$ ) were exclusion criteria, as well as diseases with potentially negative effects on growth (asthma, chronic diarrhea, celiac disease, endocrine disorders including $\mathrm{GH}$ deficiency, congenital malformations, known syndromes or chromosomal aberrations). Developmental delay and mild dysmorphic features were not considered exclusion criteria.

SGA was defined as a birth weight (BW) and/or birth length (BL) $<-2$ SDS [17]. Birth data were obtained from the preventive healthcare check-up booklet that every German child receives after birth. 49 subjects complied with these criteria. BW and BL were available for all patients, birth head circumference (BHC) in 40 of them.

At inclusion into the study, auxological measurements and laboratory analysis were performed. Height, head circumference (HC) [16], body mass index (BMI) [18], and serum IGF-I and IGFBP-3 levels $[19,20]$ were expressed as SDS for age and gender. For children under GH treatment the last height measurement before start of therapy was used. Clinical data on 47 of these children were described previously [21], as well as the results of $I G F 1$, IGF1R and SHOX mutation analysis [13]. In the latter publication the clinical data of cases I.3 and I.4 were presented, but in order to provide the reader with a full picture of the diagnostic yield of SNP arrays we include these patients also in the present paper. Informed consent was obtained from parents and if appropriate from the patient. The study was approved by the medical ethics committee of the University of Tübingen.

\section{Genetic Analysis}

Genomic DNA was extracted from peripheral venous blood samples [22]. Concentrations were measured using a Nanodrop ${ }^{\circledR}$ ND-1000 spectrophotometer (Isogen Life Science, De Meern, The Netherlands). SNP array analysis was performed using the Affymetrix GeneChip ${ }^{\circledR}$ Human Mapping 262K NspI array (Affymetrix, Santa Clara, Calif., USA), containing 262,262 25-mer oligonucleotides. An amount of $250 \mathrm{ng}$ DNA was processed according to the manufacturer's protocol. SNP copy numbers were assessed using the software program CNAG (Copy Number Analyzer for GeneChip ${ }^{\circledR}$ ) version 2.0 and 3.0 [23].

\section{Evaluation of CNVs}

Analysis was performed of deletions of at least five adjacent SNPs and a minimum region of $150 \mathrm{~kb}$ and duplications of at least seven adjacent SNPs and a minimum region of $200 \mathrm{~kb}$ [24]. The rationale of this approach was to minimize the number of false- 
positive findings. The detected CNVs were categorized into four groups: (I) known pathogenic CNVs (known microdeletion or microduplication syndrome or UPD); (II) potentially pathogenic CNVs, not described in the Database of Genomic Variants (DGV; The Centre of Applied Genomics, The Hospital for Sick Children, Toronto, Ont., Canada, http://projetcs.tcag.ca/variation/); (III) CNVs not described in the DGV, but not containing any proteincoding genes, and (IV) known polymorphic CNVs described in the DGV or observed in our in-house reference set, whereby at least 3 individuals must have been reported with the same rearrangement. All type III and IV CNVs were excluded from further analysis. The type II CNVs were further assessed with EnsEMBL release 71 (April 2013; Wellcome Trust Genome Campus, Hinxton, Cambridge, UK, http://www.ensembl.org) for gene content and DECIPHER (Wellcome Trust Genome Campus) for similar patients. The possible function of microRNAs in the CNVs was evaluated using two specific databases (miRBase and miRTarBase) $[25,26]$ and PubMed.

\section{Validation of CNVs}

Multiplex ligation-dependent probe amplification (MLPA) analysis was used to validate CNVs encompassing SHOX and IGF1R genes, using the SALSA MLPA probe mix P018C SHOX and the SALSA MLPA probe mix P217 IGF1R, respectively, according to the manufacturer's instructions (MRC-Holland, Amsterdam, The Netherlands). Amplification products were identified and quantified by capillary electrophoresis on an ABI 3130 genetic analyzer (Applied Biosystems, Nieuwerkerk aan de IJssel, The Netherlands). Analysis was performed using the GeneMark$\mathrm{er}^{\circledR}$ genotyping software (SoftGenetics, State College, Pa., USA). Thresholds for deletions and duplications were set at 0.75 and 1.25, respectively [27]. If parents were available, segregation analysis was performed by SNP array or MLPA analysis.

\section{Bioinformatics}

For all type II CNVs we used three approaches. First, we assessed whether they were located in one of the chromosomal regions associated with height in GWAS [1], and whether the genes in the deleted or duplicated regions were known to be associated with short stature in the Online Mendelian Inheritance in Man (OMIM) [28] or Gene Reference into Function (GeneRIF; http:// www.ncbi.nlm.nih.gov/gene) database. In addition, genes were mapped to biological pathways in the Gene Ontology [29] and ConsensusPath database [30] to see whether they were involved in growth. To facilitate the process of retrieving gene-specific information from databases and integrating the results we used an automated workflow that had been developed in-house.

Second, the rodent homologues were checked for three criteria: (1) higher expression in 1-week-old mouse growth plate than in 1-week-old mouse lung, kidney, and heart; (2) spatial regulation: significant difference between zones in the 1-week-old rat growth plate, and (3) temporal regulation: significant difference between 3 and 12 weeks of age in the rat growth plate using previously established mRNA expression profiles [7, 31, 32].

Third, associations were investigated for mouse growth platerelated phenotypes. For details, see Lui et al. [32] and Van Duyvenvoorde et al. [7].

\section{Results}

\section{Uniparental Disomy}

In 2 cases a UPD was found that is known to be associated with short stature. Clinical details are presented in tables 1 and 2 .

Case I. 1 showed LOH of chromosome 7 (UPD) of maternal origin (matUPD7), one of the known causes of Silver-Russell syndrome. Minor anomalies that segregate with the genotype were a prominent forehead and bone deformities (late dentition and clubfeet).

Case I.2 presented with $\mathrm{LOH}$ of chromosome 14, inherited from his mother (matUPD14). Anomalies that have previously been described in maternal UPD14 were also seen in this case, including bone deformities (kyphosis, wedge-shaped vertebra Th2) and precocious puberty.

\section{Type I CNVs}

In 3 cases a type I CNV was observed, including a duplication of the SHOX enhancer region, an IGF1R deletion, and a 22q11.21 deletion (tables 1,2).

In case I.3, a boy with severe intrauterine growth retardation, and subsequent proportionate growth failure and microcephaly in childhood, a duplication in Xp22.32, 177 $\mathrm{Kb}$ downstream of the SHOX gene, was detected (PAR probes 3-12 with MLPA analysis), as we reported previously [13]. The minimal duplication only contains the SHOX enhancer region, no known protein-coding genes, but the maximal duplicated region contains five proteincoding genes. The duplication was found to be also present in the mother who had a marginally low BW and a normal height (table 2). Sequence analysis of SHOX, $I G F 1 R$ and $I G F 1$, as well as MLPA for IGF1R showed no additional abnormalities.

In case I.4, also reported previously [13], a terminal 4.11- $\mathrm{Mb}$ deletion of the long arm of chromosome 15, including the IGF1R gene, was found. Subsequent MLPA analysis showed a de novo heterozygous deletion of all probes of $I G F 1 R$ gene (exon 1-21) including the two flanking probes located 2.0 and $2.8 \mathrm{Mb}$ downstream of $I G F 1 R$.

Patient I.5 showed a maternally inherited 22q11.21 deletion of $2.52 \mathrm{Mb}$ (velocardiofacial or DiGeorge syndrome, MIM \#192430). Maternal height was in the lownormal range.

\section{Type II CNVs}

Type II CNVs were found in 8 unrelated cases (16.7\%). Clinical and biochemical data are shown in table 3. Segregation analysis could be performed for all cases, which 
Table 1. UPDs and type I CNVs

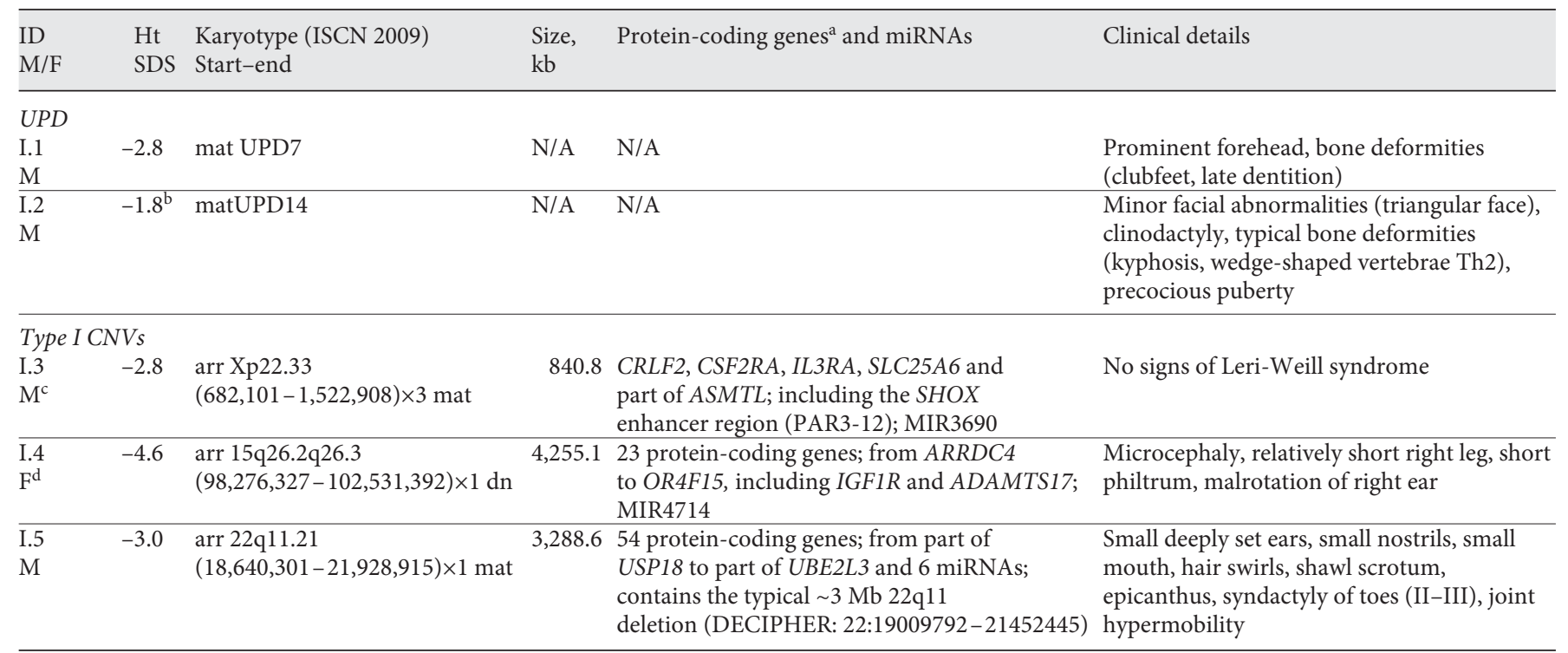

mat $=$ Maternally inherited $; \mathrm{dn}=$ de novo $; \mathrm{N} / \mathrm{A}=$ not applicable.

${ }^{a}$ For CNVs containing $\leq 5$ protein-coding genes, all protein-coding genes are shown. For CNVs containing $\geq 6$ protein-coding genes, the number, and the first and last protein-coding gene is given. ${ }^{b}$ Height SDS was $<-2$ SDS from 0 to 6 years. ${ }^{c}$ Previously published [13] as case $2 .{ }^{d}$ Previously published [13] as case 7 .

Table 2. Auxologic and biochemical features of patients with UPDs and type I CNVs

\begin{tabular}{|c|c|c|c|c|c|c|c|c|c|c|c|c|}
\hline $\begin{array}{l}\text { ID, } \\
\mathrm{M} / \mathrm{F}\end{array}$ & $\begin{array}{l}\text { Age, } \\
\text { years }\end{array}$ & $\begin{array}{l}\text { BW } \\
\text { SDS }\end{array}$ & $\begin{array}{l}\text { BL } \\
\text { SDS }\end{array}$ & $\begin{array}{l}\text { BHC } \\
\text { SDS }\end{array}$ & $\begin{array}{l}\text { Height } \\
\text { SDS }\end{array}$ & $\begin{array}{l}\text { BMI } \\
\text { SDS }\end{array}$ & $\begin{array}{l}\mathrm{HC} \\
\text { SDS }\end{array}$ & $\begin{array}{l}\text { Pat height } \\
\text { SDS }\end{array}$ & $\begin{array}{l}\text { Mat height } \\
\text { SDS }\end{array}$ & $\begin{array}{l}\text { IGF-I } \\
\text { SDS }\end{array}$ & $\begin{array}{l}\text { IGFBP-3 } \\
\text { SDS }\end{array}$ & BA/CA \\
\hline I.1, M & 2.78 & -2.5 & -0.3 & -0.5 & -2.8 & -1.9 & 0.4 & -0.1 & 0.8 & -3.8 & -0.1 & \\
\hline I.3, M & 7.47 & -3.2 & -2.7 & -2.2 & -2.8 & -3.75 & -3.3 & -0.9 & 0.2 & -2.6 & -1.2 & $6.0 / 7.5$ \\
\hline $\mathrm{I} .4, \mathrm{~F}$ & 3.29 & -1.7 & -2.3 & -1.8 & -4.6 & -1.0 & -4.8 & -0.2 & -1.5 & 0.6 & 2.6 & $2.0 / 3.3$ \\
\hline I. $5, \mathrm{M}$ & 7.41 & -2.3 & -2.0 & -1.1 & -3.0 & -0.7 & -2.7 & -1.7 & -1.3 & -2.8 & -1.5 & \\
\hline
\end{tabular}

ID = Identifier; BW = birth weight; $\mathrm{BL}=$ birth length; $\mathrm{BHC}=$ birth head circumference; $\mathrm{BMI}=$ body mass index; $\mathrm{HC}=$ head circumference; Pat = paternal; $\mathrm{Mat}=$ maternal; $\mathrm{BA} / \mathrm{CA}=$ bone age/chronological age; $\mathrm{M}=$ male; $\mathrm{F}=$ female.

led to 1 de novo CNV and 2 CNVs inherited from a parent with short stature. Genetic details and the arguments for and against possible pathogenicity of the CNV for short stature are shown in table 4 . The results of the comparison with gene expression profiles in rodent growth plates are shown in online supplementary table 1 (see www.karger.com/doi/10.1159/000367712 for all online suppl. material).

Bioinformatic analysis of the genes within the only de novo type II CNV identified six potential candidate genes (HOXD4, AGPS, PDE11A, OSBPL6, PRKRA and
PLEKHA3) and one microRNA (MIR10B) for which either associations with skeletal pathology in mice (Hoxd4) or humans (AGPS) were found, associations with height in GWAS (PDE11A) or differential expression profiles in rodents (Osbpl6, Plekha3 and Prkra) (online suppl. table 1).

The other gene for which deletions in mice produce a growth plate or other skeletal phenotype, Tnfrsf $11 \mathrm{~b}$, located in the deleted region found in case II.3, encodes osteoprotegerin (OPG), which negatively regulates osteoclast formation, and null mutations in mice cause severe 
Table 3. Auxologic and biochemical features of patients with type II CNVs (see table 2 for abbreviations)

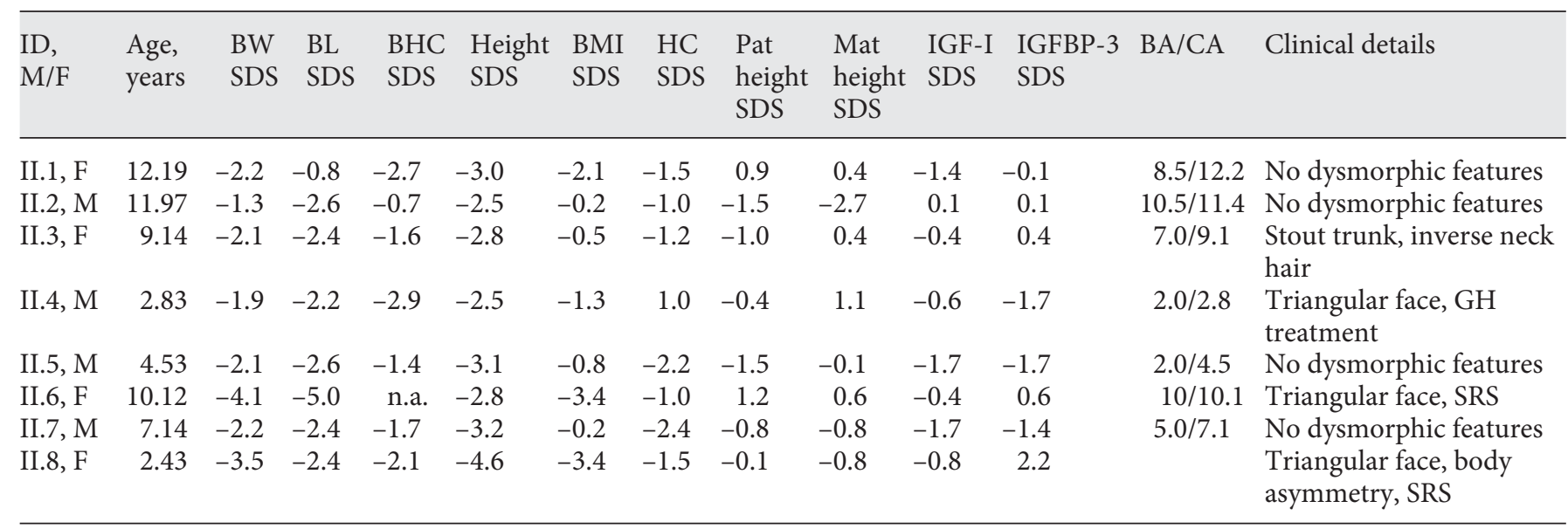

Table 4. Type II CNVs: de novo or segregating with short stature (height SDS in carrier $\leq-1.0$ )

\begin{tabular}{|c|c|c|c|c|c|}
\hline $\begin{array}{l}\text { II.1 } \\
\text { F }\end{array}$ & $\begin{array}{l}\text { arr 2q31.1q31.2 } \\
(177,004,116-179,748,446) \times 1 \mathrm{dn}\end{array}$ & $2,744.3$ & $\begin{array}{l}18 \text { protein-coding genes; } \\
\text { from HOXD3 to CCDC141, } \\
\text { including HOXD } 4, A G P S \\
\text { PDE11A, OSBPL6, PRKRA, } \\
\text { PLEKHA3; MIR10B, MIR4444-1, } \\
\text { MIR3128 }\end{array}$ & $\begin{array}{l}\text { Hoxd4 knockout mice show skeletal } \\
\text { abnormalities; AGPS associated with rhizomelic } \\
\text { chondrodysplasia; PDE11A listed as candidate } \\
\text { gene in GWAS } \\
\text { Differential expression of Osbpl6, Prkra, and } \\
\text { Plekha3 in rodent growth plate; de novo }\end{array}$ & \\
\hline $\begin{array}{l}\text { II.3 } \\
\text { F }\end{array}$ & $\begin{array}{l}\text { arr 8q24.12 } \\
(119,272,494-119,937,740) \times 3 \text { pat }\end{array}$ & 665.2 & $\begin{array}{l}\text { Part of SAMD12, } \\
\text { part of TNFRSF11B }\end{array}$ & $\begin{array}{l}\text { Father carrying the CNV is rather short } \\
(-1.0 \text { SDS }) \\
\text { Tnfrs } 11 b \text { strongly expressed in the murine growth } \\
\text { plate, knockout mice showed osteoporosis and } \\
\text { destruction of growth plate }\end{array}$ & $\begin{array}{l}\text { Father is less short } \\
\text { than his child }\end{array}$ \\
\hline
\end{tabular}

$\mathrm{dn}=$ De novo; pat $=$ paternally inherited.

${ }^{a}$ For CNVs containing $\leq 5$ protein-coding genes, all protein-coding genes are depicted. For CNVs containing $\geq 6$ protein-coding genes, the number, and the first and last protein-coding gene in the $\mathrm{CNV}$ are given.

osteoporosis, growth retardation, and destruction of the growth plate $[33,34]$. Also $D G K B$, part of which is duplicated in case II.2, can be considered as a potential candidate gene for short stature.

Five cases had inherited the CNV from a parent with a height within the normal range (online suppl. table 2). For 4 cases this makes it a priori unlikely that these CNVs are causally related to short stature, although several genes in the CNVs are preferentially expressed in the murine growth plate, or spatially or temporally expressed in the rat (online suppl. table 1). Two cases were later found to show features of Silver-Russell syndrome (II.6 and II.8), which was genetically confirmed (online suppl. table 2 ), and compatible with the phenotype. For the duplication located in the X chromosome in case II.4, the normal maternal height does not decrease the likelihood of an association with short stature, because an X-linked inheritance pattern would be expected. In fact, this duplication contains two interesting candidate genes (SERPINA7 and NRK). 


\section{Discussion}

Whole-genome SNP array analysis in 49 patients born SGA with persistent short stature led to the detection of 2 maternal UPDs, 3 CNVs that are known to cause short stature, 1 de novo deletion and $2 \mathrm{CNV}$ s segregating with short stature. The de novo 2q31.1 deletion contained several potential candidate genes (HOXD4, AGPS, PDE11A, OSBPL6, PRKRA, and PLEKHA3), and the two CNVs segregating with short stature contained genes that also could be candidates for further study ( $D G K B$ and TNFRSF11B). In addition, two genes in the duplication in Xq22.3 (SERPINA7 and NRK) may be associated with an $\mathrm{X}$-linked syndrome of growth failure based on previous similar observations.

With regard to the cases where the SNP array analysis led to the diagnosis of a syndrome known to be associated with short stature, it should be emphasized that at the time of the analysis these syndromes were not suspected. However, in retrospect, the clinical features of the children with UPD 7 and UPD14 were consistent with these diagnoses. The 22q11.21 deletion (I.5) (velocardiofacial or DiGeorge syndrome) is known to be associated with short stature and several other clinical and biochemical features [35-37].

The cases with the SHOX duplication and IGF1R deletion showed only few of the known clinical features of these syndromes, but with the clinical scores that we developed previously, there was sufficient basis for genetic testing [13]. The phenotype of case I.3, with a duplication of the SHOX downstream enhancer region, was reported in more detail in a previous paper from our group [13]. It illustrates that the clinical picture of SHOX haploinsufficiency is not only observed in cases with a SHOX mutation or deletion but also in cases with a duplication of SHOX $[38,39]$, or deletions or duplications of the downstream enhancer region (PAR probes 3-12) or upstream enhancer region [13, 40-46]. Case I.4 carries a large terminal deletion of $15 \mathrm{q}$ containing $I G F 1 R$, as recently reported [13], which is now a well-established cause of persistent short stature of SGA born children [13, 47-49].

We reasoned that some of the identified CNVs might cause short stature because they contain genes that are expressed and function in the growth plate. We therefore used existing expression microarray data to identify genes that show greater expression in mouse growth plate than in soft tissues, temporal regulation in rat growth plate, or spatial regulation in rat growth plate. For the three type II CNVs which were either de novo or segregated with short stature, this approach implicated four genes
(Osbpl6, Plekha3, Prkra and Tnfrsf11b) (online suppl. table 1). In addition, we performed a bioinformatic analysis to establish which deletions in mice produce a growth plate or other skeletal phenotype. This information, in combination with clinical data and data retrieved from online biological knowledge bases, was used to formulate the arguments pro and contra an association of these genes with short stature (summarized in table 4).

Bioinformatic analysis of case II.1 with de novo type II CNV led to several potentially interesting candidate genes (table 4). The first is HOXD4, because heterozygous and homozygous null mutations of Hoxd4 in mice exhibit homeotic transformation of the second cervical vertebrae and malformed neural arches of $\mathrm{C} 1-\mathrm{C} 3$ and of the basioccipital bone [50]. The second is PDE11A, because a SNP located within this gene is associated with adult height variation in GWAS [1]. However, the clinical syndrome of individuals with a heterozygous mutation in this gene (primary pigmented nodular adrenocortical disease, PPNAD2; MIM 610475) [51] is not consistent with the characteristics of our patient. Homozygous or compound heterozygous mutations in AGPS, the gene encoding alkyl-dihydroxyacetonephosphate synthase (alkyl-DHAP synthase) (MIM 603051), cause rhizomelic chondrodysplasia punctata type 3 (RCDP3) [52]. There are no published data on heights of heterozygous carriers, but they appear of normal stature [Dr. Nancy Braverman, pers. commun.]. Homozygous or heterozygous mutations in the PRKRA gene are associated with generalized dystonia (DYT16, MIM 612067) [53, 54]. Interestingly, Prkra is preferentially expressed in the murine growth plate and its expression is higher in the hypertrophic zone than the proliferative zone in the rat. Two other genes are also differentially expressed in rodent growth plates (Osbpl6 and Plekha3). We speculate that in this case either haploinsufficiency of one of the genes located in this region may have an impact on growth, or there may be a combined effect of haploinsufficiency of several genes in this locus.

In case II.2, the deletion of part of $D G K B$ segregates with moderate short stature of the father $(-1.5$ SDS). DGKB plays a key role in cellular processes by regulating the second messenger diacylglycerol (DAG). However, no human disorders have been associated with $D G K B$ variants. Since the mother is as short as her child $(-2.7$ and -2.5 SDS, respectively), it appears more likely that a maternal gene variant plays a role.

One of the genes in the small duplication observed in case II.3 (TNFRSF11B, encoding OPG), may be an interesting candidate gene, since Tnfrsf $11 b$ is very strongly expressed in the murine growth plate and temporally regu- 
lated in the rat growth plate, and null mutations in mice cause severe osteoporosis, growth retardation, and destruction of the growth plate $[33,34]$. However, homozygous mutations in this gene cause juvenile Paget disease [55] and are not associated with abnormal body growth. The duplication also contains part of the SAMD12 gene, for which no function is known.

Out of the 5 cases in whom the CNV was transmitted from a parent with normal height, case II.4 is noteworthy. This refers to the maternal Xq22.3 duplication containing SERPINA7, encoding thyroxine-binding globulin (TBG). In three papers, TBG excess by gene duplication was reported to be associated with short stature [56-58], which responded to $\mathrm{T}_{3}$ treatment in terms of catch-up growth [56]. In one of these cases, GH deficiency was observed [57]. However, in two other reports $[59,60]$ no mention was made about short stature. Our patient had indeed an elevated serum TBG, so that this may be a further example of the possible role of TBG excess on growth. Another patient with an identical CNV (DECIPHER, id 249139) and short stature (height -2.1 SDS) was reported by us in a previous paper (case II.23, online suppl. tables [7]). Interestingly, another gene in this region is strongly expressed in the murine growth plate (Nrk), so it is also possible that growth failure is associated with overexpression of NRK.

In conclusion, whole-genome SNP array analysis in this exploratory study on 49 patients born SGA with persistent short stature identified 13 CNVs (27\%), including
2 maternal UPDs (UPD 7 and UPD14) and 3 CNVs for which the association with short stature is virtually certain (SHOX duplication, IGF1R deletion and 22.q11 deletion). This percentage is in the same range as observed in previous studies [7-9]. Several of the deleted genes in the de novo $\mathrm{CNV}$ may be considered potential candidate genes, but confirmation is needed by future studies. From the two type II CNVs segregating with short stature, $D G K B$ and TNFRSF11B deserve further study, and we speculate that a SERPINA7 or NRK duplication may be associated with X-linked short stature.

\section{Acknowledgments}

We are grateful to Pfizer for an unrestricted grant for carrying out the SNP arrays, to the patients and their parents for participating in this study, and to the physicians for referring the patients. Special thanks go to Linda Johnston-Rohrbasser and Linda Fryklund of the NESTEGG Consortium. The contributions of J.C.L. and J.B. were supported by the Intramural Research Program of the Eunice Kennedy Shriver National Institute of Child Health and Human Development (NICHD), NIH.

\section{Disclosure Statement}

J.M.W. has served on advisory boards for Tercica, Ipsen, Pfizer, Prolor, Teva and Biopartners and has received speaker honorariums from Pfizer, Lilly, Ipsen and Ferring. The remaining authors have no conflicts of interest to disclose.

\section{References}

1 Lango Allen H, Estrada K, Lettre G, et al: Hundreds of variants clustered in genomic loci and biological pathways affect human height. Nature 2010;467:832-838.

-2 Oostdijk W, Grote FK, de Muinck KeizerSchrama S, Wit JM: Diagnostic approach in children with short stature. Horm Res 2009; 72:206-217.

-3 Seaver LH, Irons M: ACMG practice guideline: genetic evaluation of short stature. Genet Med 2009;11:465-470.

-4 Wit JM, Kiess W, Mullis P: Genetic evaluation of short stature. Best Pract Res Clin Endocrinol Metab 2011;25:1-17.

5 Wit JM, van Duyvenvoorde HA, Scheltinga SA, de Bruin S, Hafkenscheid L, Kant SG, Ruivenkamp CA, Gijsbers AC, van Doorn J, Feigerlova E, Noordam C, Walenkamp MJ, Claahsen-van de Grinten H, Stouthart P, Bonapart IE, Pereira AM, Gosen J, Delemarrevan de Waal $\mathrm{H}$, Hwa $\mathrm{V}$, Breuning $\mathrm{MH}$, Domene HM, Oostdijk W, Losekoot M: Ge- netic analysis of short children with apparent growth hormone insensitivity. Horm Res Paediatr 2012;77:320-333.

6 Clayton PE, Cianfarani S, Czernichow P, Johannsson G, Rapaport R, Rogol A: Management of the child born small for gestational age through to adulthood: a consensus statement of the International Societies of Pediatric Endocrinology and the Growth Hormone Research Society. J Clin Endocrinol Metab 2007;92:804-810.

7 Van Duyvenvoorde HA, Lui JC, Kant SG, Oostdijk W, Gijsbers AC, Hoffer MJ, Karperien M, Walenkamp MJ, Noordam C, Voorhoeve PG, Mericq V, Pereira AM, Claahsen-van de Grinten HL, van Gool SA, Breuning $\mathrm{MH}$, Losekoot $\mathrm{M}$, Baron J, Ruivenkamp $\mathrm{CA}$, Wit JM: Copy number variants in patients with short stature. Eur J Hum Genet 2014;22:602-609.

-8 Zahnleiter D, Uebe S, Ekici AB, Hoyer J, Wiesener A, Wieczorek D, Kunstmann E, Reis A,
Doerr HG, Rauch A, Thiel CT: Rare copy number variants are a common cause of short stature. PLoS Genet 2013;9:e1003365.

$\checkmark 9$ Canton AP, Costa SS, Rodrigues TC, Bertola DR, Malaquias AC, Correa FA, Arnhold IJ, Rosenberg C, Jorge AA: Genome-wide screening of copy number variants in children born small for gestational age reveal several candidate genes involved in growth pathways. Eur J Endocrinol 2014;171:253-262.

10 Cirulli ET, Goldstein DB: Uncovering the roles of rare variants in common disease through whole-genome sequencing. Nat Rev Genet 2010;11:415-425.

11 Dauber A, Lafranchi SH, Maliga Z, Lui JC, Moon JE, McDeed C, Henke K, Zonana J, Kingman GA, Pers TH, Baron J, Rosenfeld RG, Hirschhorn JN, Harris MP, Hwa V: Novel microcephalic primordial dwarfism disorder associated with variants in the centrosomal protein ninein. J Clin Endocrinol Metab 2012;97:E2140-E2151. 
$\checkmark 12$ Dauber A, Stoler J, Hechter E, Safer J, Hirschhorn JN: Whole-exome sequencing reveals a novel mutation in CUL7 in a patient with an undiagnosed growth disorder. J Pediatr 2013;162:202-204.

-13 Caliebe J, Broekman S, Boogaard M, Bosch CA, Ruivenkamp CA, Oostdijk W, Kant SG, Binder G, Ranke MB, Wit JM, Losekoot M: IGF1, IGF1R and SHOX mutation analysis in short children born small for gestational age and short children with normal birth size (idiopathic short stature). Horm Res Paediatr 2012;77:250-260.

$\checkmark 14$ Wit JM, Clayton PE, Rogol AD, Savage MO, Saenger PH, Cohen P: Idiopathic short stature: definition, epidemiology, and diagnostic evaluation. Growth Horm IGF Res 2008; 18 : 89-110.

15 Dauber A, Yu Y, Turchin MC, Chiang CW, Meng YA, Demerath EW, Patel SR, Rich SS, Rotter JI, Schreiner PJ, Wilson JG, Shen Y, $\mathrm{Wu}$ BL, Hirschhorn JN: Genome-wide association of copy-number variation reveals an association between short stature and the presence of low-frequency genomic deletions. Am J Hum Genet 2011;89:751-759.

-16 Prader A, Largo RH, Molinari L, Issler C: Physical growth of Swiss children from birth to 20 years of age. First Zurich longitudinal study of growth and development. Helv Paediatr Acta Suppl 1989;52:1-125.

-17 Niklasson A, Ericson A, Fryer JG, Karlberg J, Lawrence C, Karlberg P: An update of the Swedish reference standards for weight, length and head circumference at birth for given gestational age (1977-1981). Acta Paediatr Scand 1991;80:756-762.

18 Cole TJ, Freeman JV, Preece MA: Body mass index reference curves for the UK, 1990. Arch Dis Child 1995;73:25-29.

19 Blum WF, Ranke MB, Kietzmann K, Gauggel E, Zeisel HJ, Bierich JR: A specific radioimmunoassay for the growth hormone $(\mathrm{GH})$ dependent somatomedin-binding protein: its use for diagnosis of GH deficiency. J Clin Endocrinol Metab 1990;70:1292-1298.

-20 Blum WF, Breier BH: Radioimmunoassays for IGFs and IGFBPs. Growth Regul 1994; 4(suppl 1):11-19.

21 Caliebe J, Martin DD, Ranke MB, Wit JM: The Auxological and Biochemical Continuum of Short Children Born Small for Gestational Age (SGA) or with Normal Birth Size (Idiopathic Short Stature). Int J Pediatr Endocrinol 2010;2010:852967.

22 Miller SA, Dykes DD, Polesky HF: A simple salting out procedure for extracting DNA from human nucleated cells. Nucleic Acids Res 1988;16:1215.

23 Nannya Y, Sanada M, Nakazaki K, Hosoya N, Wang L, Hangaishi A, Kurokawa M, Chiba S, Bailey DK, Kennedy GC, Ogawa S: A robust algorithm for copy number detection using high-density oligonucleotide single nucleotide polymorphism genotyping arrays. Cancer Res 2005;65:6071-6079.
24 Hehir-Kwa JY, Egmont-Petersen M, Janssen IM, Smeets D, van Kessel AG, Veltman JA: Genome-wide copy number profiling on high-density bacterial artificial chromosomes, single-nucleotide polymorphisms, and oligonucleotide microarrays: a platform comparison based on statistical power analysis. DNA Res 2007;14:1-11.

25 Kozomara A, Griffiths-Jones S: miRBase: annotating high confidence microRNAs using deep sequencing data. Nucleic Acids Res 2014;42:D68-D73.

26 Hsu SD, Tseng YT, Shrestha S, Lin YL, Khaleel A, Chou CH, Chu CF, Huang HY, Lin CM, Ho SY, Jian TY, Lin FM, Chang TH, Weng SL, Liao KW, Liao IE, Liu CC, Huang HD: miRTarBase update 2014: an information resource for experimentally validated miRNAtarget interactions. Nucleic Acids Res 2014; 42:D78-D85.

27 Lalic T, Vossen RH, Coffa J, Schouten JP, Guc-Scekic M, Radivojevic D, Djurisic M, Breuning MH, White SJ, den Dunnen JT: Deletion and duplication screening in the DMD gene using MLPA. Eur J Hum Genet 2005;13: 1231-1234.

28 McKusick VA: Mendelian Inheritance in Man. A Catalog of Human Genes and Genetic Disorders. Baltimore, Johns Hopkins University Press, 1998.

29 Ashburner M, Ball CA, Blake JA, Botstein D, Butler H, Cherry JM, Davis AP, Dolinski K, Dwight SS, Eppig JT, Harris MA, Hill DP, Issel-Tarver L, Kasarskis A, Lewis S, Matese JC, Richardson JE, Ringwald M, Rubin GM, Sherlock G: Gene ontology: tool for the unification of biology. The Gene Ontology Consortium. Nat Genet 2000;25:25-29.

30 Kamburov A, Pentchev K, Galicka H, Wierling C, Lehrach H, Herwig R: ConsensusPathDB: toward a more complete picture of cell biology. Nucleic Acids Res 2011;39:D712-D717.

31 Lui JC, Andrade AC, Forcinito P, Hegde A, Chen W, Baron J, Nilsson O: Spatial and temporal regulation of gene expression in the mammalian growth plate. Bone 2010;46: 1380-1390.

32 Lui JC, Nilsson O, Chan Y, Palmer CD, Andrade AC, Hirschhorn JN, Baron J: Synthesizing genome-wide association studies and expression microarray reveals novel genes that act in the human growth plate to modulate height. Hum Mol Genet 2012;21:5193-5201.

33 Yun TJ, Tallquist MD, Aicher A, Rafferty KL, Marshall AJ, Moon JJ, Ewings ME, Mohaupt M, Herring SW, Clark EA: Osteoprotegerin, a crucial regulator of bone metabolism, also regulates B-cell development and function. J Immunol 2001;166:1482-1491.

34 Mizuno A, Amizuka N, Irie K, Murakami A, Fujise N, Kanno T, Sato Y, Nakagawa N, Yasuda H, Mochizuki S, Gomibuchi T, Yano K, Shima N, Washida N, Tsuda E, Morinaga T, Higashio K, Ozawa H: Severe osteoporosis in mice lacking osteoclastogenesis inhibitory factor/osteoprotegerin. Biochem Biophys Res Commun 1998;247:610-615.
35 Ryan AK, Goodship JA, Wilson DI, Philip N, Levy A, Seidel H, Schuffenhauer S, Oechsler H, Belohradsky B, Prieur M, Aurias A, Raymond FL, Clayton-Smith J, Hatchwell E, McKeown C, Beemer FA, Dallapiccola B, Novelli G, Hurst JA, Ignatius J, Green AJ, Winter RM, Brueton L, Brondum-Nielsen K, Scambler PJ: Spectrum of clinical features associated with interstitial chromosome 22q11 deletions: a European collaborative study. J Med Genet 1997;34:798-804.

36 Botto LD, May K, Fernhoff PM, Correa A, Coleman K, Rasmussen SA, Merritt RK, O'Leary LA, Wong LY, Elixson EM, Mahle WT, Campbell RM: A population-based study of the 22q11.2 deletion: phenotype, incidence, and contribution to major birth defects in the population. Pediatrics 2003;112: 101-107.

-37 Bassett AS, Chow EW, Husted J, Weksberg R, Caluseriu O, Webb GD, Gatzoulis MA: Clinical features of 78 adults with 22q11 deletion syndrome. Am J Med Genet A 2005;138:307313.

- 38 Benito-Sanz S, Barroso E, Heine-Suner D, Hisado-Oliva A, Romanelli V, Rosell J, Aragones A, Caimari M, Argente J, Ross JL, Zinn AR, Gracia R, Lapunzina P, Campos-Barros A, Heath KE: Clinical and molecular evaluation of SHOX/PAR1 duplications in LeriWeill dyschondrosteosis and idiopathic short stature. J Clin Endocrinol Metab 2011; 96:E404-E412.

39 Iughetti L, Capone L, Elsedfy H, Bertorelli R, Predieri B, Bruzzi P, Forabosco A, El Kholy M: Unexpected phenotype in a boy with trisomy of the SHOX gene. J Pediatr Endocrinol Metab 2010;23:159-169.

40 Benito-Sanz S, Thomas NS, Huber C, Gorbenko del BD, Aza-Carmona M, Crolla JA, Maloney V, Rappold G, Argente J, CamposBarros A, Cormier-Daire V, Heath KE: A novel class of pseudoautosomal region 1 deletions downstream of SHOX is associated with Leri-Weill dyschondrosteosis. Am J Hum Genet 2005;77:533-544.

41 Benito-Sanz S, del Blanco DG, Aza-Carmona M, Magano LF, Lapunzina P, Argente J, Campos-Barros A, Heath KE: PAR1 deletions downstream of SHOX are the most frequent defect in a Spanish cohort of Leri-Weill dyschondrosteosis probands. Hum Mutat 2006; 27:1062.

42 Albuisson J, Schmitt S, Baron S, Bezieau S, Benito-Sanz S, Heath KE: Clinical utility gene card for: Leri-Weill dyschondrosteosis and Langer mesomelic dysplasia. Eur J Hum Genet 2012;20.

-43 Barroso E, Benito-Sanz S, Belinchon A, YusteCheca P, Gracia R, Aragones A, Campos-Barros A, Heath KE: Identification of the first de novo PAR1 deletion downstream of SHOX in an individual diagnosed with Leri-Weill dyschondrosteosis. Eur J Med Genet 2010;53: 204-207. 
44 Benito-Sanz S, Royo JL, Barroso E, PaumardHernandez B, Barreda-Bonis AC, Liu P, Gracia R, Lupski JR, Campos-Barros A, GomezSkarmeta JL, Heath KE: Identification of the first recurrent PAR1 deletion in Leri-Weill dyschondrosteosis and idiopathic short stature reveals the presence of a novel SHOX enhancer. J Med Genet 2012;49:442-450.

-45 Benito-Sanz S, Aza-Carmona M, Rodriguez-Estevez A, Rica-Etxebarria I, Gracia R, CamposBarros A, Heath KE: Identification of the first PAR1 deletion encompassing upstream SHOX enhancers in a family with idiopathic short stature. Eur J Hum Genet 2012;20:125-127.

- 46 Kant SG, Broekman SJ, de Wit CC, Bos M, Scheltinga SA, Bakker E, Oostdijk W, van der Kamp HJ, van Zwet EW, van der Hout AH, Wit JM, Losekoot M: Phenotypic characterization of patients with deletions in the 3'-flanking SHOX region. PeerJ 2013;1:e35.

47 Walenkamp MJ, de Muinck Keizer-Schrama S, de Mos M, Kalf ME, van Duyvenvoorde HA, Boot AM, Kant SG, White SJ, Losekoot M, den Dunnen JT, Karperien M, Wit JM: Successful long-term growth hormone therapy in a girl with haploinsufficiency of the insulin-like growth factor-I receptor due to a terminal 15 q26.2 $\rightarrow$ qter deletion detected by multiplex ligation probe amplification. J Clin Endocrinol Metab 2008;93:2421-2425.

48 Ester WA, van Duyvenvoorde HA, de Wit CC, Broekman AJ, Ruivenkamp CA, Govaerts LC, Wit JM, Hokken-Koelega AC, Losekoot M: Two short children born small for gestational age with insulin-like growth factor 1 receptor haploinsufficiency illustrate the heterogeneity of its phenotype. J Clin Endocrinol Metab 2009;94:4717-4727.
49 Klammt J, Kiess W, Pfaffle R: IGF1R mutations as cause of SGA. Best Pract Res Clin Endocrinol Metab 2011;25:191-206.

50 Horan GS, Kovacs EN, Behringer RR, Featherstone MS: Mutations in paralogous Hox genes result in overlapping homeotic transformations of the axial skeleton: evidence for unique and redundant function. Dev Biol 1995; 169:359-372.

51 Horvath A, Boikos S, Giatzakis C, RobinsonWhite A, Groussin L, Griffin KJ, Stein E, Levine E, Delimpasi G, Hsiao HP, Keil M, Heyerdahl S, Matyakhina L, Libe R, Fratticci A, Kirschner LS, Cramer K, Gaillard RC, Bertagna X, Carney JA, Bertherat J, Bossis I, Stratakis CA: A genome-wide scan identifies mutations in the gene encoding phosphodiesterase 11A4 (PDE11A) in individuals with adrenocortical hyperplasia. Nat Genet 2006; 38:794-800.

52 Itzkovitz B, Jiralerspong S, Nimmo G, Loscalzo M, Horovitz DD, Snowden A, Moser A, Steinberg S, Braverman N: Functional characterization of novel mutations in GNPAT and AGPS, causing rhizomelic chondrodysplasia punctata types 2 and 3. Hum Mutat 2012;33: 189-197.

53 Seibler P, Djarmati A, Langpap B, Hagenah J, Schmidt A, Bruggemann N, Siebner H, Jabusch HC, Altenmuller E, Munchau A, Lohmann K, Klein C: A heterozygous frameshift mutation in PRKRA (DYT16) associated with generalised dystonia in a German patient. Lancet Neurol 2008;7:380-381.
54 Camargos S, Scholz S, Simon-Sanchez J, Paisan-Ruiz C, Lewis P, Hernandez D, Ding J, Gibbs JR, Cookson MR, Bras J, Guerreiro R, Oliveira CR, Lees A, Hardy J, Cardoso F, Singleton AB: DYT16, a novel young-onset dystonia-parkinsonism disorder: identification of a segregating mutation in the stress-response protein PRKRA. Lancet Neurol 2008; 7:207-215.

55 Brunetti G, Marzano F, Colucci S, Ventura A, Cavallo L, Grano M, Faienza MF: Genotypephenotype correlation in juvenile Paget disease: role of molecular alterations of the TNFRSF11B gene. Endocrine 2012;42:266271.

56 Alain N, Zipf WB: Short stature and thyroxine-binding globulin excess: improvement with triiodothyronine treatment. Pediatrics 1988;81:674-679.

57 Nakai A, Shigematsu Y, Kikawa Y, Sudo M: A case of familial thyroxine-binding globulin excess associated with growth hormone deficiency. Acta Paediatr Jpn 1994;36:408-411.

58 Mori Y, Jing P, Kayama M, Fujieda K, Hasegawa T, Nogimori T, Hirooka Y, Mitsuma T: Gene amplification as a common cause of inherited thyroxine-binding globulin excess: analysis of one familial and two sporadic cases. Endocr J 1999;46:613-619.

59 Mori Y, Miura Y, Takeuchi H, Igarashi Y, Sugiura J, Saito H, Oiso Y: Gene amplification as a cause of inherited thyroxine-binding globulin excess in two Japanese families. J Clin Endocrinol Metab 1995;80:3758-3762.

-60 Onenli-Mungan N, Yuksel B, Ozer G, Denli G, Topaloglu AK, Teker Z: Familial thyroxinbinding globulin excess with ichthyosis: a case report. Turk J Pediatr 2004;46:174-176. 